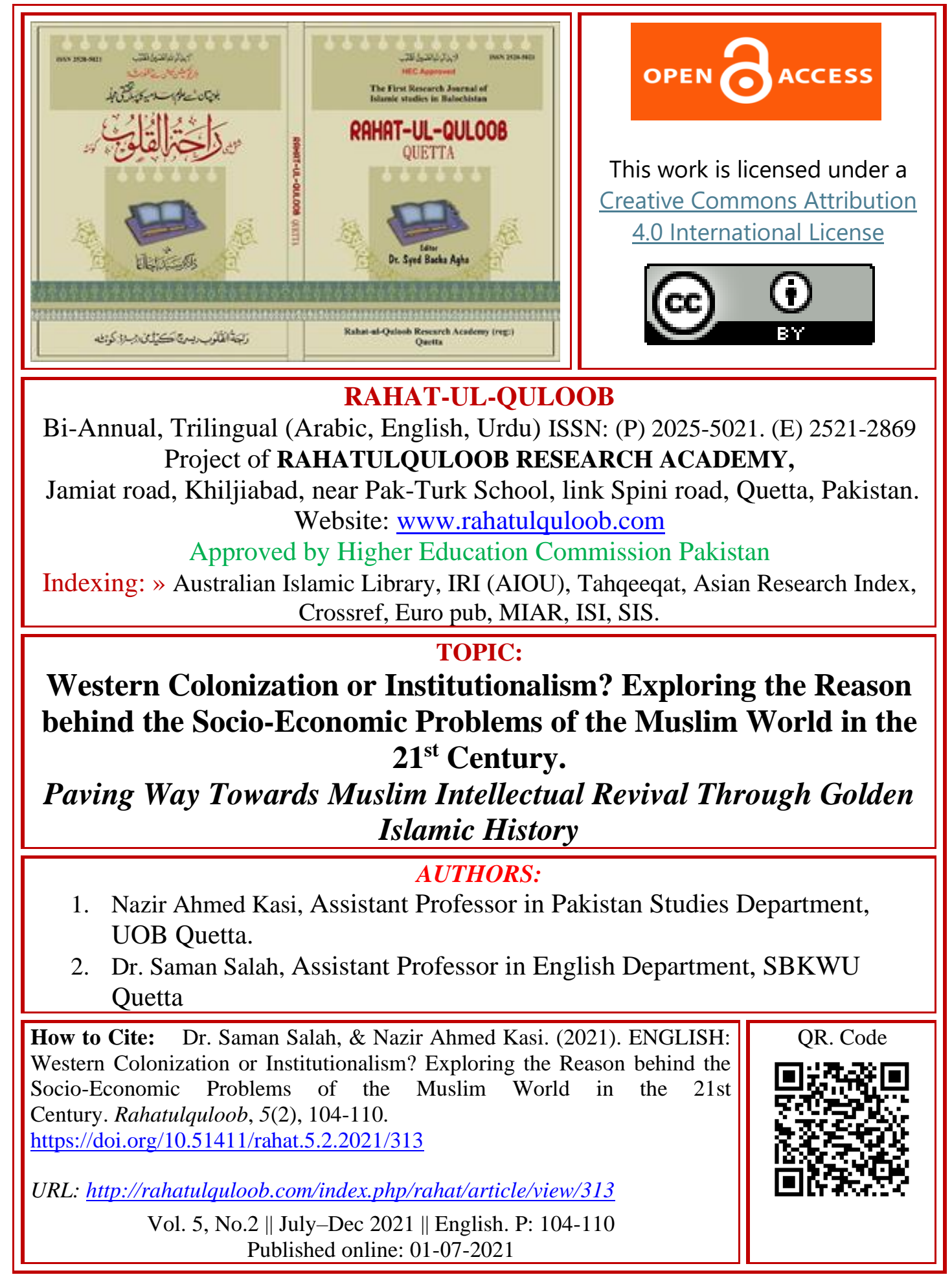




\title{
Western Colonization or Institutionalism? Exploring the Reason behind the Socio-Economic Problems of the Muslim World in the $21^{\text {st }}$ Century. Paving Way Towards Muslim Intellectual Revival Through Golden Islamic History
}

\author{
${ }^{1}$ Nazir Ahmed Kasi, ${ }^{2}$ Dr. Saman Salah
}

\section{ABSTRACT:}

The present study is an attempt to explore the reasons behind the socio-economic problems of the Muslim world since 9/11 incident. It draws upon the theoretical framework of Ahmet T. Kuru who is an independent Turkish Islamic scholar. Kuru asserts that issues of underdevelopment, viciousness and dictatorship in the Muslim world Since 9/11, have pulled in much consideration in the world of academics and media. It has been observed that about $66 \%$ of the entire wars happened in the major Muslim countries. Besides, in 2009, around 33\% of all minor military clashes occurred in countries with major Muslim population. As indicated by the "United States-based think-tank Freedom House, in 2013, less than one-fifth of 49 Muslim countries were democracies, whereas three-fifths of the world's 195 countries were classified as democracies" (Freedom in the world, 2013). Human development and economic performance of the countries with major Muslim population has not performed well in areas for instance, life expectancy, teaching, schooling and net public pay per capita. Using the theoretical underpinnings of Kuru, this paper follows a qualitative research design with a descriptive, exploratory and interpretive approach using content analysis as a method to trace the historical trajectory of the Muslim intellectuals and merchants who truly worked for the cause of religion and kept themselves away from politics. The findings of the study indicate that the prevailing decline of the Muslim world is due to the emergence of the Ulema-State alliance which has join its hands with the military state and solely work for the national interest. The paper comes up with the recommendations that there is a need of real Muslim intellectuals and the revival of old Islamic system which can reform and enlighten the lost splendor of the Muslim world.

Keywords: Socio-Economic Problems, decline, Muslim World, Content Analysis

\section{Introduction}

In the Muslim world, there are mainly three schools of thought regarding ferocity, autocracy and impecuniousness. The first school of thought makes certain "Islamic characteristics" and some historical contexts to be accountable for the concerned problem. This school of thought comes under the umbrella of "essentialists" (Ayoob, 2009). Both in the western as well as in the Islamic world, this school of thought is used in various versions by the Islamic critics. Another school of thought is called the 
"anti-colonial" or the "post-colonial" thought. This school of thought holds Western colonization as well as the present exploitation of the Muslim world resources to be responsible for the concerned issue (Shilliam, 2010). Since, this is an anti-Western perspective, therefore it is very popular among the Islamists and secularists with similar ideologies. Besides, "essentialists" and "anti-colonial" school of thoughts, Volpi and Cavatorta (2013) explain that there is a third school of thought named "institutionalism" which holds that the Muslim world lacks proper institutions which is the major cause of impecuniousness in the Muslim countries. However, the present research finds a research gap within the theoretical underpinnings of the above stated schools of thought.

\section{Literature Review}

The $21^{\text {st }}$ century, particularly after the tragic incident of $9 / 11$ involves a complex discussion on the association between religion, society, institutions, economics and politics (Lincoln, 2010). Some critics hold that there is a clear impact of religion on politics, economy and the social behavior (Norris \& Inglehart, 2011). While other scholars opine that factor such as politics, institutions, law and economics affect religiosity (Eberle, 2002). Here the question arises as to whether religion affects a country's stance, political, social and economic dynamics or religion itself is affected by these factors? Some researchers in the field of religion and social work state,

"Social scientists of the latter half of the century were for the most part content to ignore religion almost entirely," and that evidence-based practice seems, at least to secular practitioners, the very antithesis of faith-based practice" (McGrew \& Cnaan, 2006, p. 22).

Since, Islam is the most popular and universal religion in the world. Therefore, different researchers have conducted studies on Islam, the Muslim world and its association with social behavior, politics and economics. While commenting on the economic conditions of the Muslim world, Sirageldin and Anwar in their research explained that "The contemporary Muslim world is still emerging from the long night of colonial hegemony: a period during which the key institutions of Muslim society were supplanted and substituted, the moral fibre of society was destroyed, and an 'unrepresentative' leadership was groomed to power, producing the most serious schism within Muslim society. The Muslim society of today is not yet a society on its own. It is still under the shadow of the Western system and, as such, it is doubtful how 'representative' of the Islamic ethos its current behaviour can be." (1995). A famous critic in the field of Islamic studies, Hamid (2016) explains that the Islamic states have been under the turmoil of secularism as well as colonialism. The bureaucracies with huge power, each holding its own social interest though brought about "modernity," however, with weapons, technology and military (Fuller, 2002). The loyalty of the citizens turned towards nations and they neglected Islamic laws which led to the decline of the Muslim world (Bayat, 2013; Ayoob, 2004). These studies however are general in nature and mainly focus on the global decline of the 
Muslim world without tracing the historical trajectory of the Muslim intellectuals. Besides, to date back, there is no study which deals with the issues of underdevelopment, viciousness and dictatorship in the Muslim world Since 9/11 and this study fills in this gap.

\section{Discussion}

Keeping in view the three schools of thought about ferocity, autocracy and impecuniousness, a political scientist Kuru who is born in Turkey disagrees with all these three schools of thoughts. He traces the historical trajectory of the Muslim world between $8^{\text {th }}$ and $12^{\text {th }}$ centuries. Kuru proves Islamic progress by tracing the economic and intellectual history of the Muslims which in other words, is a challenge to the "essentialists". Kuru explains that in the middle of the $18^{\text {th }}$ century, the Muslim world had given a clear downfall to the economic crisis and poverty and that was also the time of Western colonization. In this way, Kuru also challenges the Anti-colonial school of thought. In case of institutionalism, he asserts that since Institutions are "human created" therefore there is a need to trace Islamic history and to deeply study the old Islamic institutions which had proved beneficial for the entire nations and the ones which could not continue in the further history. There exists a strong relation between religious, constitutional, academic and monetary classes. The success of the Muslim or the European world is determined by these class relations. Kuru explains that in history, the Muslim intellectuals and educated mercantile led the nations to progress with their unconditional leadership. Unfortunately, it was in the $11^{\text {th }}$ century that "Ulema state- alliance" grew powerful and led down the Muslim intellectuals in the Islamic world. Hence, Kuru asserts that the early Islamic history is full of Islamic scholars, real leaders and bourgeois. However, the ulema state alliance is responsible for the lack of progress in the Islamic world. During early Islam, Europe was under the turmoil and confusion of military rule and devout convention. Moreover, the Muslim merchants and the Muslim philosophers were at their intellectual peak. The subsequent history, however, was altered in the $11^{\text {th }}$ century when an alliance came into existence between the religious scholars belonging to conventional group and the military states. The marginalization of the real Islamic leaders, intellectual as well as Muslim merchants (Bourgeois) happened due to this emerging alliance and this alliance has been a bone of contention in the progress of the Muslim world since it has suppressed innovation and contest. It must be noted that under the umbrella of Quran and Hadith, State-Ulema alliance is not mandatory nor it is a part of early Islamic history. However, the separation of religion and politics is clearly indicated in Islamic history. One of the early Persian/Sassanid doctrine (pre-Islamic) which is erroneously ascribed to Islamic history is mingling religion and politics. The Muslim thinkers and the Muslim merchants between $8^{\text {th }}$ and $12^{\text {th }}$ centuries have made the world wonder with their educational philosophy and trade expertise. These Muslim thinkers not only contributed to the world of academics such as astronomy, cartography, statistics, agriculture, philosophy but also in the field of banking and finance, making proper 
cheques as well as formulated a finance system which ran the entire system smoothly on fair grounds.

Moreover, in history, Islamic thinkers stayed away from politics since they thought political power as leading to "corruption". Due to this reason, they trusted on commerce for finance which led them to form healthy relations with the merchants. Philosophers and religious thinkers were either supported by the merchants or they themselves were merchants. A study conducted between the $8^{\text {th }}$ and $11^{\text {th }}$ century indicated that,

"Only nine percent of 4,000 Islamic scholars were funded by the state; the remaining 91 percent were financed by commerce and the middle class" (Kuru, 2019).

Moreover, since the early Muslim thinkers did not participate in politics, there vision was broad with liberty of speech. The political rulers disenchanted and intimidated them. Due to the maltreatment of the descendants of the Holy Prophet (PBUH), the Ummayads went through the dearth of religious rightfulness and legitimacy. Since the Ummayads used ferocity for gaining power. The Abassids, later continued the same cycle of vehemence and this estrangement from the authorities of the state continued even during the time of Abassids. During this period, the religious scholars who did not depend on the state namely imams "Abu Hanifa, Malik, Hanbal and Shafii" formed the jurisprudence of Sunni in four schools. This showed that these four imams did not accept the state interest and its frivolities. On account of their dissenting ideologies, they were maltreated and finally persecuted by the state authorities. Even the Shia imams suffered and were poisoned as well.

It was in the $11^{\text {th }}$ century that the Sunni Muslim world, with the development of "din wa dawla [religion and state] alliance" went through major changes. This alliance formed a major relation between the military state and the Ulema. Hence the decline of the Muslim world started due to marginalization of the real Muslim thinkers and the hegemony of those Ulemas who became "state servants". Hence "the Islamic researchers changed into state-workers through state-drove madressahs, the militarisation of the economy happened through the iqta arrangement of land residency and expense farming, and the minimization of savants and vendors" (Kuru, 2019). Under the Abbasid caliph, the competing Shia empires led to this transformation. "The Mutazilites in Iraq, Fatimids in Egypt and Buyids in Baghdad" (Kuru, 2019). The Persian prime minister named "Nizamul Mulk" who belonged to the Seljuk dynasty, strategically got successful in making "Nizamiya madressahs". Hence, the Ulema state alliance, right after the "Nizamiya madressahs" was consolidated throughout the Muslim world. Imam Ghazali, was one of those Muslim scholars who established Sunni tenet and deplored the "Mutazilites" and the "Shias". Under these transformations, the military class became dominant. On the other hand, the merchants and the real Islamic thinkers started suffering. This was since economically, through iqta the military was provided with all major finances as land revenues. The strength of the Ulema state alliance happened with the "Mangols of Asia" and the "Crusaders from Europe" 
respectively. There was a need of refuge to the Muslim countries and therefore, military left no stone unturned to provide security to the weak Muslim countries through religious elites which enhanced the marginalization of the merchants and the free thinkers. Ultimately, "the Ayyubids/Mamluks, Ottomans, Safavids and Mughals espoused the Seljuk model of ulema-state alliance" (Kuru, 2019). Although, it was till the $16^{\text {th }}$ century that the financial development of the Mughals, Safavids and the Ottoman occurred, however, the innovation of the merchants and the independent scholars continued to throttle by the Ulema state alliance. Kuru while discussing Iran states,

"In Iran it fails to explain the role of the merchant-Shia ulema - instead of ulemastate - alliance, in powerfully opposing the state, which resulted in the 1906 and 1979 revolutions. In Iran, before the 1979 revolution, Shia ulema were financed by citizens' private money (khums). In Mughal India, apart from conservative Aurangzeb's period, an adversarial relationship existed between Muslim ulema and the Mughal kings, especially Akbar and Jahangir" (Kuru, 2019).

In a society ruled by the Muslims, the issue of viciousness cannot be fully explored without tracing the trajectory of historical dictatorship. This historical dictatorship is clearly reflected even in the last century. The Islamists or the seculars, both have revealed authoritarianism, leading to civil conflict, extremism and war by trailing repressive strategies. The leaders who were secular, mostly had a background of military, which ultimately led to the deprecation of the real thinkers as well as merchants. Kuru states,

"Authoritarian rulers have relied on alliances with the ulema and oil rents to sustain their rule; 22 out of 28 rentier states in the current world are Muslim, deriving more than 40 percent of their revenues from oil. Instead of the traditional land rents, the ulema-state alliance today is reinforced by rentierism fueled by oil revenues in countries such as Saudi Arabia, Iran and Algeria etc. Oil rents have contributed to the dominance of the ulema-state alliance and the marginalisation of the bourgeoisie" (Kuru, 2019).

It can be said ironically that Europe, separated the church from the state in the $11^{\text {th }}$ century which brought many positive changes such as Renaissance, geographical explorations, academic vivacity, Reformation, industrial revolution, printing press and the development of many world class universities in the West of Europe within 500 years. However, since, the Muslim world, did not go under such revolutions, therefore, it lost its strength with each passing century. Historically, the major three inventions of the Europe were the printing press, the gun powder and the nautical compass. Out of these three, only the gunpowder was incorporated by the Muslim world under the so called Ulema influence. Moreover, the major threat considered by the Muslim military rulers under Ulema state alliance was the printing press which according to this alliance was a potential threat to their dominance. Therefore, for 
about 280 years, the printing press did not get importance in the Muslim world. Such unfamiliarity with the printing press led to overwhelming outputs, for instance, "Around the 1800s, the average literacy rate in Western Europe was 31 percent; in the Ottoman empire it was only one percent, explaining the path-dependent literacy gap between the Western and Islamic civilization" (Kuru, 2019).

\section{Conclusion}

The economic and social issues of the Muslim world have nothing to do with the Islamic beliefs anti- colonialism, institutionalism or Western Colonisation. The reason behind the non-progression of the Muslim world lies beneath the Ulema state alliance which works for their own interests, relish domination over dogma and hegemony including rentierism constructed oil rents. The discussion of this paper comes up with the recommendations that there is a need of independent and unconditional Muslim thinkers who, with the help of their inventiveness as well as novelty can truly take the responsibility of reforming the Muslim intellectual vitality and dynamism.

\section{Bibliography/ References}

Ayoob, M. (2004). Political Islam: image and reality. World Policy Journal, 21(3), 1-14.

Ayoob, M. (2009). The many faces of political Islam: religion and politics in the Muslim world. University of Michigan Press.

Bayat, A. (Ed.). (2013). Post-Islamism: The Many Faces of Political Islam. OUP USA.

Eberle, C. J. (2002). Religious conviction in liberal politics. Cambridge University Press.

Freedom in the world (2013). The Annual Survey of Political Rights and Civil Liberties. New York, Toronto, Oxford.

Fuller, G. E. (2002). The future of political Islam. Foreign Affairs, 48-60.

Hamid, S. (2016). Islamic exceptionalism: How the struggle over Islam is reshaping the world. St. Martin's Press.

Kuru, A. T. (2019). Islam, authoritarianism, and underdevelopment: A global and historical comparison. Cambridge University Press.

Lincoln, B. (2010). Holy terrors: Thinking about religion after September 11. University of Chicago Press.

McGrew, C. C., \& Cnaan, R. A. (2006). Finding congregations: Developing conceptual clarity in the study of faith-based social services. Journal of Religion \& Spirituality in Social Work: Social Thought, 25(3-4), 19-37.

Norris, P., \& Inglehart, R. (2011). Sacred and secular: Religion and politics worldwide. Cambridge University Press.

Shilliam, R. (Ed.). (2010). International relations and non-Western thought: Imperialism, colonialism and investigations of global modernity. Routledge.

Sirageldin, I., \& Anwar, M. (1995). Islam, Society, and Economic Policy [with Comments]. The Pakistan Development Review, 34(4), 457-480. Retrieved September 18, 2020, from http://www.jstor.org/stable/41260134

Volpi, F., \& Cavatorta, F. (Eds.). (2013). Democratization in the Muslim World: Changing Patterns of Authority and Power. Routledge. 